\title{
Study of Odonata Diversity in Kerangas Forest Sukadamai Village and Punai Beach Simpang Pesak, Belitung Timur
}

\author{
Pratama Bimo Purwanto", Mokhammad Nur Zaman, Abellia Ike P, Mushawir Akbar, Marwan Arief \\ Biology Department, Faculty of Science and Technology, UIN Sunan Kalijaga \\ Jl. Marsda Adisucipto No. 1 Yogyakarta 55281, Indonesia. Tel. + 62-274-540971, Fax. + 62-274-519739 \\ Email: bimopurwanto91@gmail.com
}

\begin{abstract}
Belitung is known as the biggest tin mining in Indonesia. Besides that, Belitung also has a lot of biological resources, that is Odonata (dragonfly). The research was conducted in June 2018 by exploration in Belitung, particularly in Punai beach and Kerangas forest (ex-tin mining) area. There is found 17 type of dragonfly such as Ichtinogomphus decoratus., Macrogomphus sp., Orthetrum sabina., Nannophya pygmaea., Neurothemis fluctuans., Rhodothemis rufa., Rhyothemis phyllis., Urothnemis signata., Pseudagrion coomansi., Ceriagrion cerinorubellum., Acisoma panorpoides., Brachydiplax chalybea., Diplacodes nebulosa., Orthetrum pruinosum., Agriocnemis femina., Agriocnemis pygmaea., and Ischnura senegalensis. All species were conducted to find out the diversity using Shannon-Wiener index and resulting 2,77 index.
\end{abstract}

Keywords: Belitung, Diversity, Odonata

\section{INTRODUCTION}

Belitung is located in Karimata's strait that connected between Sumatra and Kalimantan. East Belitung as an observation location have about 250.691 ha areas (BAPPEDA, 2017). A large number of mines in Belitung makes a lot excavation which causes damage to the land.

According to Whitten (1984), Kerangas in Sumatra can be found only in Bangka and Belitung, whereas in a small area also found in the Natuna. According to Hilwan Iwan (2005) several types of plants exist in East Belitung Kerangas forest that is Gelam Melaleuca leucadendron., Belangeran Shorea belangeran., Keletaan Melastoma malabathricum L. Kerangas forest, Belitung has many beaches, one of them is Punai beach which used as the location for research. Belitung has Kerangas and coastal areas that interesting to research Odonata diversity. Odonata known as dragonflies is a group of insects that are medium to large and often has an attractive color. This insect uses most entire its life to fly. Dragonflies also have a slim body with two pairs of wings (Rizal et al., 2015). Dragonflies are divided into two sub-orders, namely Anisoptera (ordinary dragonflies) and Zygoptera (needle dragonflies). Dragonflies are insects that have important values for the environment. Its existence in nature is a marker of changes quality of the environment (Nur Zaman et al., 2017). Dragonflies have two habitats that are water and air. Female Odonata in carrying out oviposition choose clear and clean aquatic habitats because the lymph nodes are vulnerable to polluted water quality (Borror et al., 1992; Jhon, 2001).

Dragonflies in the environment can be an aquatic bioindicators that indirectly indicate clean water around the environment. The changes to dragonfly populations can be used as the first step to mark pollution (polluted environment) (Wisnu pamungkas, 2015). Indonesia has a lot of natural damage especially in Belitung because of mining activities. The research is expected to become a benchmark about dragonfly for preserving nature in this region. In addition, this research is also expected to be a reference for further research and can examine deeper biodiversity on this tin island.

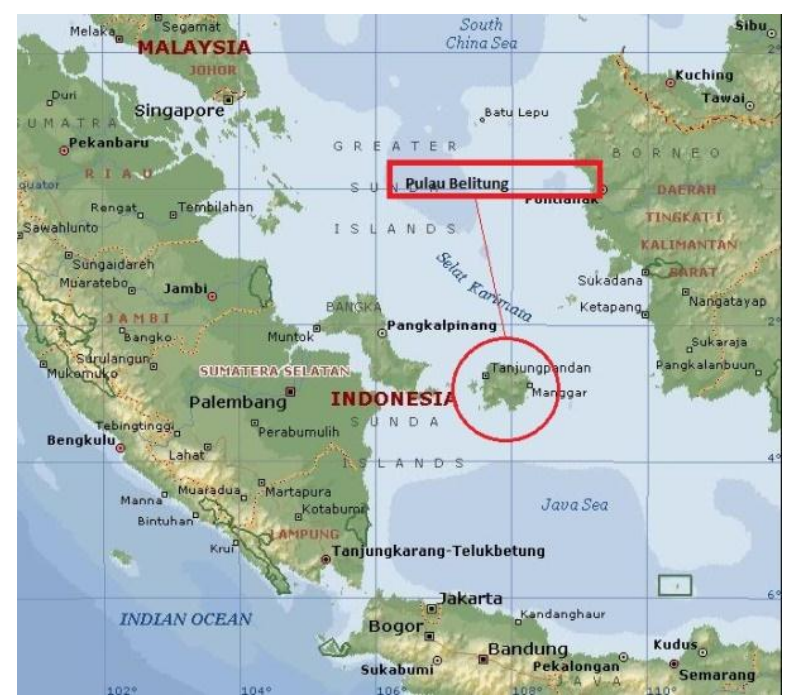

Figure 1. Belitung Island.

\section{MATERIALS AND METHODS}

\section{Date and Location}

This research was carried out in Kerangas forest, Mengkubang, Damar and Punai beach, Simpang Pesak, East Belitung. The Kerangas forest is an ex-tin mining area that has sandy soil and dominated by hard plants. The former mining quarry will cause pool water and 
eventually form-lake, which later in this lake dragonfly data collection will be carried out.

In the coastal area, the pole is used as the location for collecting data, then surrounded swamp area which is covered with trees and some grasses. The study was conducted on June 15 until 17, 2018, and the coast ended on June 20 until 23, 2018, from 08:00 a.m to 11:00 p.m and afternoon 03:00 p.m 05:00 p.m local area, data collection in Kerangas forest was carried out.

\section{Research Method}

Retrieval of dragonfly data in Kerangas forest is carried out by tracing area of lake with approximately $50 \mathrm{~m}^{2}$ and a number of puddles in the forest are alleged to be dragonfly habitat. In the coastal area data collection is carried out along the swamp area of $\pm 300 \mathrm{~m}$. Each type of dragonfly obtained then taken using a digital camera and is numbered by each individual species. For sampling, there were several types of dragonflies that had not been identified in the field. The sampling of dragonflies was carried out using nets and dragonflies which were successfully caught and then placed in the box-sample for further identification.

\section{Data Analysis}

Data obtained (species type and number of individuals per species), then calculated by the Shannon-Wiener formula to determine the species diversity index, the Shannon-Wiener formula.

$$
\mathrm{H}^{\prime}=-\sum \mathrm{Pi} \ln (\mathrm{Pi}), \text { where } \mathrm{Pi}=(\mathrm{ni} / \mathrm{N})
$$

Explanation:

$\mathrm{H}^{\prime}=$ Shannon-Wiener diversity index

$\mathrm{ni}=$ Number of i-type individuals

$\mathrm{N}=$ Number of individuals of all types

Criteria for the Shannon-Wiener (H') diversity index value:

$\mathrm{H}^{\prime}<1$ : low diversity

$1<\mathrm{H}^{\prime} \leq 3$ : moderate diversity

H'> 3: high diversity (Odum, 1993).

\section{RESULTS AND DISCUSSION}

The results in two different places exploration, namely Kerangas and Punai beach, were found 17 species, 12 types of suborder Anisoptera and 5 types of suborder Zyggoptera. The species found consists of the order Gomphiadae, Libellulidae, and Coenagrionidae. Data species found by two exploration places can be seen in Table 1.
Table 1. Types of dragonflies found in the Kerangas forest area.

\begin{tabular}{lll}
\hline NO & Spesies & Family \\
\hline & Sub Ordo Anisoptera & \\
\hline 1 & Ichtinogomphus decoratus. & Gomphiadae \\
3 & Macrogomphus sp. & Gomphiadae \\
4 & Orthetrum sabina. $*$ & Libellulidae \\
5 & Nannophya pygmaea. (jantan) & Libellulidae \\
6 & Nannophya pygmaea. (betina) & Libellulidae \\
7 & Rhodothemis rufa. & Libellulidae \\
8 & Rhyothemis phyllis. $*$ & Libellulidae \\
9 & Urothnemis signatha. $*$ & Libellulidae \\
\hline NO & Species & Libellulidae \\
\hline & Suborder Zygoptera & Family \\
\hline 1 & Pseudagrion coomansi. $*$ & Coenagrionidae \\
2 & Ceriagrion cerinorubellum. & Coenagrionidae \\
\hline
\end{tabular}

Table 2. Types of dragonflies found in the Punai beach area.

\begin{tabular}{lll}
\hline NO & Species & Family \\
\hline 1 & Suborder Anisoptera & \\
2 & Acisoma panorpoides. & Libellulidae \\
3 & Urothnemis signatha. ${ }^{*}$ & Libellulidae \\
4 & Rhyothemis phyllis. ${ }^{*}$ & Libellulidae \\
5 & Brachydiplax chalybea. & Libellulidae \\
6 & Orthetrum sabina. ${ }^{*}$ & Libellulidae \\
7 & Orthetrum pruinosum. & Libellulidae \\
\hline NO & Species & Libellulidae \\
\hline & Suborder Zygoptera & Family \\
\hline 1 & Agriopnemis femina. (male) & Coenagrionidae \\
2 & Agriopnemis femina. (female) & Coenagrionidae \\
3 & Agriopnemis pgymea. & Coenagrionidae \\
4 & Ceriagrion cerinorubellum. $*$ & Coenagrionidae \\
5 & Ischnura senegalensis. (male) & Coenagrionidae \\
6 & Ischnura senegalensis. (female) & Coenagrionidae \\
\hline$*:$ The same types of dragonflies are found in the Kerangas Forest and \\
Punai Beach
\end{tabular}

The dragonflies obtained in two same places were found Ceriagrion cerinorubellum., Orthetrum sabina., Rhyothemis phyllis., and Urothnemis signatha. All species found counted the number of species which was then calculated by Shannon-Wiener index to determine the diversity. The results of diversity index calculation are presented in Table 3 . 
Table 3. Dragonfly diversity index in Kerangas forest and Punai beach.

\begin{tabular}{|c|c|c|c|c|c|c|c|c|c|}
\hline \multirow[t]{2}{*}{ No. } & \multirow[t]{2}{*}{ Suborder } & \multirow[t]{2}{*}{ Family } & \multirow[t]{2}{*}{ Species } & \multicolumn{2}{|c|}{$\begin{array}{c}\text { Total Each } \\
\text { Habitat }\end{array}$} & \multirow[t]{2}{*}{$\begin{array}{l}\text { Total/ } \\
\text { Species }\end{array}$} & \multirow[t]{2}{*}{$\mathbf{P i}$} & \multirow[t]{2}{*}{ Ln Pi } & \multirow[t]{2}{*}{$\mathbf{H}^{\prime}$} \\
\hline & & & & HK & $\mathbf{P P}$ & & & & \\
\hline 1. & Anisoptera & Gomphiadae & Ichtinogomphus decoratus. & 1 & - & 1 & 0,006 & $-5,050$ & 0,03 \\
\hline 2. & & Gomphiadae & Macrogomphus sp. & 3 & - & 3 & 0,019 & $-3,951$ & 0,08 \\
\hline 3. & & Libellulidae & Orthetrum sabina. & 7 & 9 & 16 & 0,103 & $-2,277$ & 0,23 \\
\hline 4. & & Libellulidae & Nannophya pygmaea. (male) & 15 & - & 15 & 0,096 & $-2,342$ & 0,23 \\
\hline 5. & & Libellulidae & $\begin{array}{l}\text { Nannophya pygmaea. } \\
\text { (female) }\end{array}$ & 10 & - & 10 & 0,064 & $-2,747$ & 0,18 \\
\hline 6. & & Libellulidae & Neurothemis fluctuans. & 5 & - & 5 & 0,032 & $-3,440$ & 0,11 \\
\hline 7. & & Libellulidae & Rhodothemis rufa. & 2 & - & 2 & 0,013 & $-4,357$ & 0,06 \\
\hline 8. & & Libellulidae & Rhyothemis phyllis. & 5 & 5 & 10 & 0,064 & $-2,747$ & 0,18 \\
\hline 9. & & Libellulidae & Urothnemis signata. & 5 & 1 & 6 & 0,038 & $-3,258$ & 0,13 \\
\hline 10. & & Libellulidae & Acisoma panorpoides. & - & 8 & 8 & 0,051 & $-2,970$ & 0,15 \\
\hline 11. & & Libellulidae & Brachydiplax chalybea. & - & 1 & 1 & 0,006 & $-5,050$ & 0,03 \\
\hline 12. & & Libellulidae & Diplacodes nebulosa. & - & 5 & 5 & 0,032 & $-3,440$ & 0,11 \\
\hline 13. & & Libellulidae & Orthetrum pruinosum. & - & 2 & 2 & 0,013 & $-4,357$ & 0,06 \\
\hline 14. & Zyggoptera & Coenagrionidae & Agriocnemis femina. (male) & - & 5 & 5 & 0,032 & $-3,440$ & 0,11 \\
\hline 15. & & Coenagrionidae & $\begin{array}{l}\text { Agriocnemis femina. } \\
\text { (female) }\end{array}$ & - & 7 & 7 & 0,045 & $-3,104$ & 0,14 \\
\hline 16 & & Coenagrionidae & Agriocnemis pygmaea. & - & 11 & 11 & 0,071 & $-2,652$ & 0,19 \\
\hline 17. & & Coenagrionidae & $\begin{array}{l}\text { Ischnura senegalensis. } \\
\text { (male) }\end{array}$ & - & 13 & 13 & 0,083 & $-2,485$ & 0,21 \\
\hline 18. & & Coenagrionidae & $\begin{array}{l}\text { Ischnura senegalensis. } \\
\text { (female) }\end{array}$ & - & 12 & 12 & 0,077 & $-2,565$ & 0,20 \\
\hline 19. & & Coenagrionidae & Pseudagrion coomansi. & 5 & - & 5 & 0,032 & $-3,440$ & 0,11 \\
\hline 20 & & Coenagrionidae & Ceriagrion cerinorubellum. & 10 & 9 & 19 & 0,122 & $-2,105$ & 0,26 \\
\hline Total & & & & 53 & 79 & 132 & & & 2,77 \\
\hline
\end{tabular}

* HK: Kerangas Forest. PP: Punai Beach.
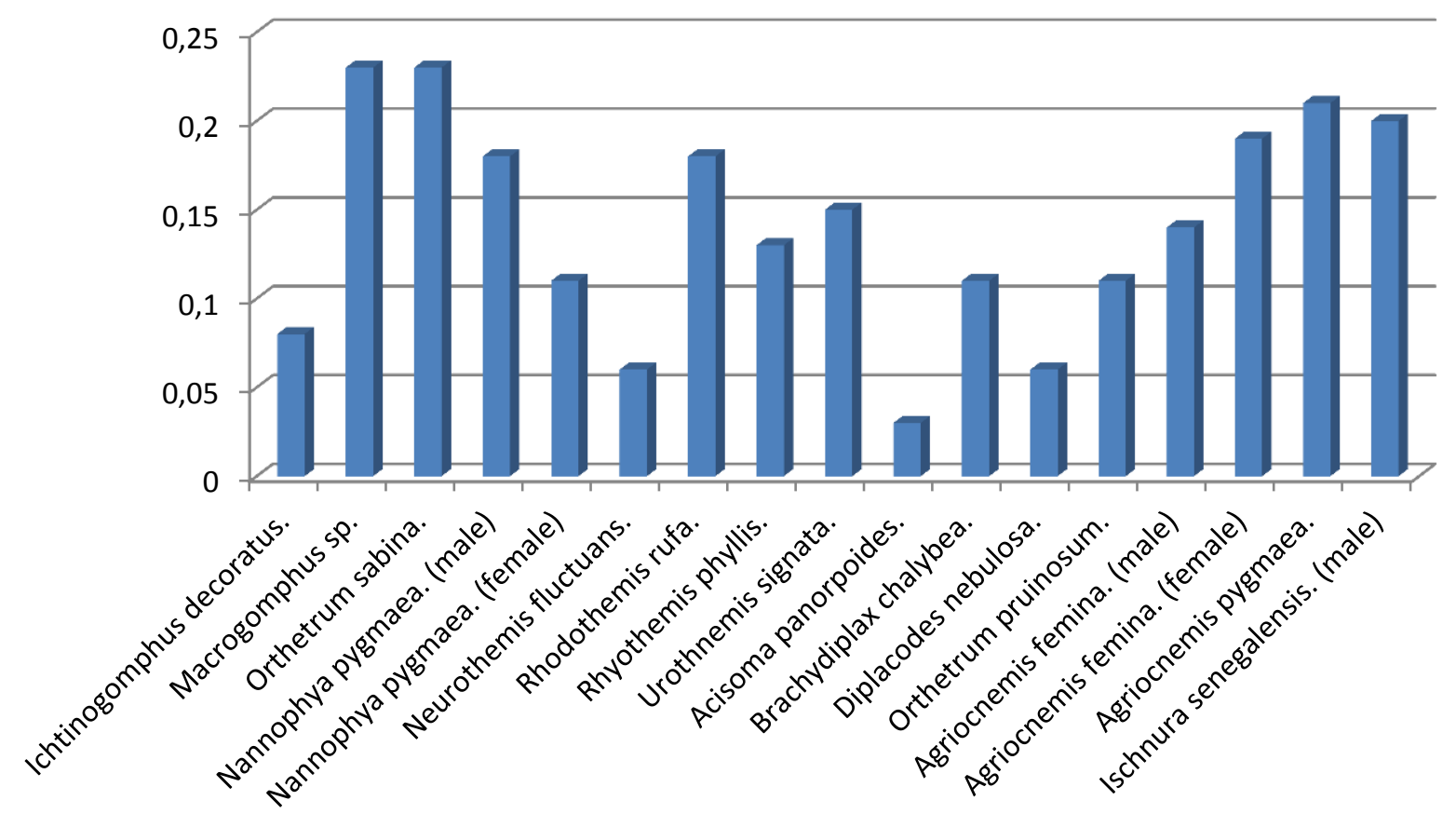

Figure 2. Graphic of dragonfly diversity index in Kerangas forest and Punai beach. 
The average diversity index of the two places were obtained 2.77. According to Odum (1993) number 2.77 is a medium diversity $\left(1<\mathrm{H}^{\prime} 3\right)$. Dragonfly diversity index from the highest to the lowest order, Orthetrum sabina., $(0,23)$ Nannophya pygmaea male $(0,23)$ female $(0,18)$., Ischnura senegalensis male $(0,21)$ female $(0,20)$. Agriopnemis pgymea. $(0,19)$ Rhyothemis phyllis. $(0,18)$ Acisoma panorpoides. $(0,15)$ Agriopnemis femina. male $(0,15)$ female $(0,14)$ Urothnemis signatha. $(0,13)$ Neurothemis fluctuans. $(0,11)$ Diplacodes nebulosa. $(0,11)$ Macrogomphus sp. Rhodothemis rufa. $(0,06)$ Orthetrum pruinosum. $(0,06)$ Brachydiplax chalybea $(0,03)$ Ichtinogomphus decoratus. $(0,03)$.

Orthetrum sabina has the highest diversity index (0.23). This dragonfly lives solitary with a wide distribution (Susanti, 1998) and has a high tolerance for changes in environmental conditions, including polluted waters (Rahadi et al., 2013). Orthetrum sabina can be found throughout the year, and prey on insects that are relatively large in sizes such as butterflies and even cannibals to fellow dragonflies. Nannophya pygmaea male has a diversity index same with Orthetrum sabina $(0,23)$. Nannophya pygmaea male and female are found abundant in Kerangas forest precisely in the waters, these dragonflies live clustered and perch on the grass in the edge of waters.

Fewer found the Zygoptera than Anisoptera in Kerangas, this is due to the lake as a data taken were the former mine, so the water is contained mining compounds. This, concerning the existence of dragonflies, especially needles (Zygoptera) can be found around clean river waters and flows with moderate sunlight intensity or under tree shade (Rahadi et al., 2013). In Kerangas there are also very few trees so that the high intensity of the sun makes needle dragonflies rarely to found and only exist two types Pseudagrion coomansi., and Ceriagrion cerinorubellum.

Punai Beach is a swamp area with swamp edges covered with trees and bushes. So that in the Punai coastal area is found in needle dragonfly (Zygoptera). Punai coastal swamps are often found in water plants such as (Ipomoea aquatic, Limnocharis sp.) which bound microhabitat of several types of needle dragonflies (Rahadi et al., 2013).

\section{CONCLUSIONS}

Odonata exploration in Kerangas forest in Mengkubang Village and Punai Beach, East Belitung obtained 17 types of dragonflies. The 12 types of suborder Anisoptera and 5 types of suberoder Zygoptera. The dragonflies obtained in two same places are Ceriagrion cerinorubellum., Orthetrum sabina., Rhyothemis phyllis., and Urothnemis signatha. The results of data collection of dragonflies in two places were calculated by Diversity Index using Shanon-Wiener formula of (2.77). This value is classified as moderate diversity.

The average diversity index of the two places were obtained 2.77 which is as a medium diversity $\left(1<\mathrm{H}^{\prime} 3\right)$ (Odum, 1993). Dragonfly diversity index from the highest to the lowest order are, Orthetrum sabina., $(0,23)$ Nannophya pygmaea male $(0,23)$ female $(0,18)$, Ischnura senegalensis male $(0,21)$ female $(0,20)$. Agriopnemis pgymea. $(0,19)$ Rhyothemis phyllis. $(0,18)$ Acisoma panorpoides. $(0,15)$ Agriopnemis femina. male $(0,15)$ female $(0,14)$ Urothnemis signatha. $(0,13)$ Neurothemis fluctuans. $(0,11)$ Diplacodes nebulosa. $(0,11)$ Macrogomphus sp. Rhodothemis rufa. $(0,06)$ Orthetrum pruinosum. $(0,06)$ Brachydiplax chalybea. $(0,03)$ Ichtinogomphus decoratus. $(0,03)$.

Orthetrum sabina has the highest diversity index (0.23), it is the same diversity index with Nannophya pygmaea male $(0,23)$, and the lowest index is Ichtinogomphus decoratus $(0,03)$.

\section{REFERENCES}

Badan Perancanaan Pembangunan Daerah (BAPPEDA) Kabupaten Belitung Timur. 2017

Borror, D. J., Triplehorn. C. A dan Johnson, N. F. 1996. Pengenalan Pelajaran Serangga, Edisi keenam. Terjemahan oleh Partosoedjono. UGM Press. Yogyakarta

Diagal Wisnu Pamungkas, Muhammad Ridwan. Keragaman jenis capung dan capung jarum (Odonata) di beberapa sumber air di Magetan, Jawa Timur. Prosiding Seminar Nasional Masyarakat Biodiversitas Indonesia. Volume 1, Nomor 6, September 2015 ISSN: 2407-8050 Halaman: 1295-1301

Iwan Hilwan Karakteristik Biofisik Pada Berbagai Kondisi Hutan Kerangas Di Kabupaten Belitung Timur, Provinsi Kepulauan Bangka Belitung. Jurnal Silvikultur Tropika. Vol. 06 No. 1, April 2015, Hal 59-65 ISSN: 2086-8227

Nur Zaman et al. 2017. Inventarisasi Keanekaan Anggota Ordo Odonata di Cagar Alam Nusakambangan Timur dan Sekitarnya Kabupaten Cilacap, Jawa Tengah. Jurnal SEMNAS UMS 2016

Odum, Eugene P. 1993. Dasar-Dasar Ekologi. UGM Press: Yogyakarta.

Rahadi WS, Feriwibisono B, Nugrahani MP, et al. 2013. Naga Terbang Wendit, Keanekaragaman Capung Perairan Wendit, Malang, Jawa Timur. Indonesia Dragonfly Society, Malang.

Samsul Rizal1 dan Mochamad Hadi2. Inventarisasi Jenis Capung (Odonata) Pada Areal Persawahan Di Desa Pundenarum Kecamatan Karangawen Kabupaten Demak. BIOMA, Juni 2015 ISSN: 1410-8801 Vol. 17, No. 1, Hal. 16-20

Samways, M.J. 2008. Dragonflies and Damselflies of South Africa. Sofia. Pensoft Publisher.

Susanti S. 1998. Seri Panduan Lapangan Mengenal Capung. Puslitbang Biologi-LIPI, Bogor.

Whitten AJ, Anwar J, Damanik SJ, Hisyam N. 1984. Ekologi Ekosistem Sumatera. Yogyakarta: UGM Press. 